Review Article

\title{
An Updated Review on the Secondary Metabolites and Biological Activities of Aspergillus ruber and Aspergillus flavus and Exploring the Cytotoxic Potential of Their Isolated Compounds Using Virtual Screening
}

\author{
Fadia S. Youssef $\mathbb{D}^{1}$ and Abdel Nasser B. Singab $\mathbb{D}^{1,2}$ \\ ${ }^{1}$ Department of Pharmacognosy, Faculty of Pharmacy, Ain-Shams University, Cairo 11566, Egypt \\ ${ }^{2}$ Center for Drug Discovery Research and Development, Faculty of Pharmacy, Ain-Shams University, Cairo 11566, Egypt \\ Correspondence should be addressed to Fadia S. Youssef; fadiayoussef@pharma.asu.edu.eg and Abdel Nasser B. Singab; dean@ \\ pharma.asu.edu.eg
}

Received 16 September 2020; Revised 3 January 2021; Accepted 7 January 2021; Published 31 January 2021

Academic Editor: Mohammad Faisal

Copyright (C) 2021 Fadia S. Youssef and Abdel Nasser B. Singab. This is an open access article distributed under the Creative Commons Attribution License, which permits unrestricted use, distribution, and reproduction in any medium, provided the original work is properly cited.

\begin{abstract}
The secondary metabolites and biological activities of Aspergillus ruber and Aspergillus flavus were comprehensively reported. About 70 compounds were isolated from both species that belong to different classes using conventional and advanced chromatographic techniques and unambiguously elucidated employing one- and two-dimensional nuclear magnetic resonance (1D and 2D NMR) and high resolution mass spectrometry (HRMS). Some of them displayed promising antiviral, anti-inflammatory, and antioxidant activities. In silico studies were conducted on human cyclin-dependent kinase 2 (CDK-2), human DNA topoisomerase II (TOP-2), and matrix metalloprotinase 13 (MMP-13) in an effort to explore the cytotoxic potential of the diverse compounds obtained from both Aspergillus species. 1,6,8-Trihydroxy-4-benzoyloxy-3-methylanthraquinone (23) revealed the most firm fitting with the active pockets of CDK-2 and MMP-13; meanwhile, variecolorin $\mathrm{H}$ alkaloid (14) showed the highest fitting within TOP-2 with $\Delta \mathrm{G}$ equals to $-36.51 \mathrm{kcal} / \mathrm{mole}$. Thus, fungal metabolites could offer new drug entities for combating cancer. Relevant data about both Aspergillus species up to August 2020 were gathered from various databases comprising Scifinder (https://scifinder.cas.org/scifinder/login) for secondary metabolite-related studies; meanwhile, for biology-related articles, data were collected from both PubMed (http://www.ncbi.nlm.nih.gov/pubmed/) and Web of Knowledge (http://www.webofknowledge.com) as well.
\end{abstract}

\section{Introduction}

Fungi have been recently considered as a promising source of secondary metabolites that elicited a wide range of beneficial values both on the therapeutic and commercial scales. Recently, fungal metabolites have gained a great attention as an everlasting source of precious compounds that can serve as novel entities for various therapeutic approaches [1]. These metabolites belong to a vast array of chemical classes represented mainly by terpenoids, alkaloids, peptides, lactones, and steroids. Meanwhile, to these metabolites, various biological activities were assigned as anticancer, antiviral, antibacterial, and anti-inflammatory activities [2]. Fungi possess the advantage that they can be effectively cultured giving a high rate of reproduction with concomitant production of active metabolites [3]. Besides, many fungal metabolites showed suitable oral-bioavailability and appropriate physico-chemical characters being safer than synthetic moieties that are critical in the formulation of different dosage forms $[1,4]$.

Although, a large number of pharmaceutical products such as penicillins, griseofulvin, fucidin and ergot containing pharmaceutical products are of fungal origin but 
studies performed on fungal metabolites are still quite small $[5,6]$.

Fungal metabolites are usually isolated from the fungal culture medium undergoing fermentation followed by its extraction employing various solvents and its subsequent evaporation under vacuum at $40^{\circ} \mathrm{C}$. The obtained extract is subjected to different conventional and advanced chromatographic techniques for the isolation of metabolites [7]. Meanwhile, the isolated fungal metabolites are structurally elucidated using 1D and 2D NMR (one- and two-dimensional nuclear magnetic resonance) and MS (mass spectrometry). The absolute configurations were further confirmed via Marfey's reactions in addition to Mosher's reaction and other chemical structural modification procedures [8].

Genus Aspergillus is a highly popular fungus which includes many species from which many metabolites belonging to different classes such as alkaloids, steroids, polyketides, peptides, and terpenoids were isolated. Some of these metabolites showed outstanding biological activities, particularly anticancer and antimicrobial $[9,10]$. In this review, the secondary metabolites and biological activities of two Aspergillus species, namely, Aspergillus ruber and Aspergillus flavus, were comprehensively reported. Data were collected in an effort to give a full picture about the chemistry and biology of these two species that undoubtedly could help other researchers who wish to undergo further studies on these two reported species. The data compiled in this review were collected from various databases including PubMed (http:// www.ncbi.nlm.nih.gov/pubmed), Web of Knowledge (http:// www.webofknowledge.com), and SciFinder (https://scifinder. cas.org/scifinder/login)Additionally, in silico virtual studies were conducted on critical enzymes involved in the formation, progression, and metastasis of cancer as well, namely, human cyclin-dependent kinase 2 (CDK-2), human DNA topoisomerase II (TOP-2), and matrix metalloprotinase 13 (MMP-13) in an effort to explore the cytotoxic potential of both Aspergillus species isolated compounds as future perspectives.

\section{Biological Activity and Secondary Metabolites Obtained from Aspergillus ruber}

A. ruber is a fungus that is popular by possessing a substantial amount of secondary metabolites belonging to various classes in which some of them showed promising biological activities. Six compounds (1-6) were isolated from $A$. ruber using various chromatographic techniques and then structurally elucidated by comparing their $1 \mathrm{D}$ and $2 \mathrm{D}$ NMR and MS with that previously reported in literature. These compounds were determined to be echinulin (1), neoechinulin A (2), erythroglaucin (3), physcion (4), flavoglaucin (5), and isodihydroauroglaucin (6). The absolute configurations of (1) and (2) were further confirmed by advanced Marfey's method in which alanine was assigned to be L-Ala. Compounds (5) and (6) were assessed for antiviral potential versus human cytomegalovirus (HCMV) and herpes simplex-1 virus (HSV-1). Both compounds displayed a promising significant antiviral potential versus HSV-1 virus displaying EC50 values of 6.95 and $4.73 \mu \mathrm{M}$, respectively, with moderate cytotoxic effect versus Vero cell. On the contrary, they showed no activity versus HCMV, in addition compound (6) revealed weak antibacterial effect [11]. Additionally, tetrahydroauroglaucin (7) was isolated in an abundant amount and low price from the fermentation culture media of the marine derived fungus, $A$. ruber. It showed a notable antibacterial activity $[12,13]$.

Besides, the cultivation of $A$. ruber obtained from crinoid on two different culture media, namely, rice solid and soybean, resulted in the variation in the obtained secondary metabolites as evidenced by the HPLC profiles of their extracts. This was followed by subsequent fractionation and purification using plethora of chromatographic techniques followed by characterization using various NMR and MS techniques that resulted in the identification of different secondary metabolites. From the soyabean extract, a new alkaloid compound, epoxyisoechinulin A (8) and fifteen known compounds (2, 9-22) were isolated. Meanwhile from the solid rice culture media, compounds $(17,4,28)$ in addition to compounds $(4,22-29)$ were identified. The known isolated compounds are preechinulin (9), cyclo(Trp-Ana) (10), questinol (11), neoechinulin A (2), neochinulin $E$ (12), neochinulin B (13), variecolorin $H(14)$, variecolorin $J(15)$, cryptoechinuline $G$ (16), dihydroxyisoechinulin A (17), 2(1,1-dimethyl-2-propen1-yl)-1H-indole-3-carboxaldenhyde (18), rubrocristin (19), neoechinulin $E$ (20), eurotinone (21), physcion (4), asperflavin (22), 1,6,8-trihydroxy-4-benzoyloxy-3-methylanthraquinone (23), 2-methyleurotinone (24), 2-hydroxydiplopterol (25), catenarin (26), 2-O-methyl-9dehydroxyeurotinone (27), and isodihydroauroglaucin (28). By comparing the metabolites obtained from both culture media, it was clearly obvious that the amount of alkaloids is higher in soybean culture medium due to its richness with nitrogen. Meanwhile, anthraquinone and polyketides are more abundant in rice culture medium that is rich in carbon, suggesting the induction of PKS (polyketide synthase) biosynthetic pathways triggered by the culture condition. However, testing the isolated compounds against a panel of microorganisms, namely, Staphylococcus aureus, Vibrio alginolyticus, Exiguobacterium aurantiacum, Vibrio cholera, Escherichia coli, Vibrio parahaemolyticus, Salmonella, Shigella castellani, Vibrio vulnificus, Bacillus cereus, Morganella morganii, and Citrobacter freundii, unfortunately showed no antibacterial activity against the tested strains [14-16]. Asperinines A (29) and B (30) are two new compounds isolated from $A$. ruber possessing tetrahydroanthrene and 1,4-anthraquinone moiety [17].

In addition, a red pigment, namely, erythroglaucin (31), was isolated from $A$. ruber through various chromatographic techniques, namely, thin layer chromatography and column chromatography. Upon reaction with ferrous ions $\left(\mathrm{Fe}^{2+}\right)$, this pigment resulted in the formation of a dark blue complex that is found to be insoluble in chloroform, ether, methanol, water, and dimethylsulfoxide [18]. Moreover, from the ether extract of $A$. ruber culture media, a yellow pigment was isolated, purified, and characterized to be physcion (4) that is soluble in chloroform but insoluble in methanol. It also possess iron chelating properties as it can react with iron forming a reddish-brown colored complex 
postulating the probability that physcion may contribute to iron metabolism or transportation via fungal cells [19].

Additionally, three compounds that are diketopiperazines possessing dehydrotryptophan moieties, namely, isoechinulins A (32), B (33), and C (34), were isolated from A. ruber; their structures were unambiguously determined using ${ }^{13} \mathrm{C}$-NMR spectral data, taking into consideration the chemical shifts and the multiplicities as well. It is noteworthy to mention that isoechinulin A (32) is a potent inhibitor to the growth of silkworm larvae [20,21]. Besides, compounds (35-36), two new compounds possessing indole moiety, were isolated from the same Aspergillus species and also displayed a potent inhibition to silkworm larvae growth $[15,16,22]$.

Furthermore, tannase enzyme was effectively produced in high yield from $A$. ruber upon culturing on solid state fermentation medium [23]. It is noteworthy to highlight that tannase is an enzyme that effectively catalyzes the deesterification of tannins to glucose and gallic acid. This enzyme is of great importance for plant biomass recycling and in treatment of tannery effluents as well in addition to its beneficial value in the production of gallic acid that is of great pharmaceutical importance (Figure 1 displays secondary metabolites isolated from A. ruber).

\section{Biological Activity and Secondary Metabolites Obtained from Aspergillus flavus}

A. flavus is a well-known saprophyte and opportunistic pathogen as well that resulted in the production of multiple secondary metabolites [24]. A. flavus was found to be the highest productive strain of kojic acid (37) that is highly produced by an amount estimated by $18.61 \mathrm{~g} / \mathrm{L}$ in a threeliter batch reactor and this production is greatly enhanced, employing the strategy of double $\mathrm{pH}$. It is noteworthy to mention that kojic acid is highly popular in pharmaceutical and cosmetic preparation as a promising whitening agent for the skin [25]. In addition, two new compounds, namely, 5acetoxy-3-hydroxy-3-methylpentanoic acid (38) and 5chloro-2-methoxy-N-phenylbenzamide (39), were isolated from $A$. flavus in addition to other known compounds which are kojic acid methyl ether (40), cyclo(leucylprolyl) (41), uracil (42), linoleic acid (43), and glycerol linoleate (44). All the isolated compounds showed no cytotoxic effect against (KB-3-1) that is a human cervix carcinoma cell [26].

In a study carried on culture filtrate of $A$. flavus, it was found that the extract is rich in flavonoid and total phenolic contents estimated by $158.33 \mathrm{mg}$ quercetin $/ \mathrm{mL}$ and $65.77 \mathrm{mg} \mathrm{GAE} / \mathrm{mL}$ of the crude extract, respectively. The crude extract displayed a potent antifungal and antibacterial activity against many common human pathogens. It also showed antioxidant activity manifested by its free radical scavenging behavior towards DPPH.(stable free diphenylpicrylhydrazyl radical) in which $700 \mu \mathrm{g} / \mathrm{mL}$ of the extract scavenged $64.53 \%$ of the free radicals. Meanwhile, $2 \mathrm{mg} / \mathrm{mL}$ of the crude extract effectively inhibits RBCs hemolysis by $70 \%$ comparable to $78 \%$ inhibition elicited by ibuprofen, a standard drug [27].
Furthermore, $A$. flavus is a source of amino peptidases which have a plethora of commercial applications among which is their utilization to enhance the functional potential of protein products and develop flavor to cheese [28].

Moreover, cyclopiazonic acid, an indole-hydrindanetetramic acid that acts as a neurotoxin, was produced by A. flavus. UHPLC triple-TOF HRMS was used to identify several CPA-type alkaloids from A. flavus, two of which were new, namely, 3-hydroxy-2-oxo CPA and 11,12-dehydro $\alpha$-CPA; meanwhile eighteen compounds were identified from it which are $\alpha$-CPA (45), $\beta$-CPA (46), $\alpha$-CPA imine (47), cAATrp 2-oxo CPA (48), speradine A-D (49-52), 3$\mathrm{OH}$-speradine A (53), speradine F (54), speradine $\mathrm{H}$ (55), cyclopiamide A-F (56-61), and cyclopiamide $J$ (62) [29].

Ustiloxin B (63), a cyclic tetrapeptide compound, asperentin (64), and aflatrem (65), an indole diterpene, were also isolated from $A$. flavus [30-32]. It is noteworthy to mention that $A$. flavus is a rich source of aflatoxins mainly aflatoxin B1 that is considered to be an aggressive hepatocarcinogen in experimental models in addition to triggering of tumors in colon and kidneys. Aflatoxin B1 is changed to aflatoxin M1 that is equally carcinogenic [33]. Figure 2 illustrates the secondary metabolites isolated from Aspergillus flavus. Additionally, LC-MS analysis of the ethyl acetate extract of $A$. flavus associated with the soft coral Sarcophyton ehrenbergi led to the identification of seven compounds, namely, asperorydine B (66), 4-methyl-5,6dihydro-2H-pyran-2-one (67), speradine A (53), maltoryzine (68), aflatoxine B1, asperorydine $G(69)$, and asperorydine $M$ (70) [34], (Figure 3 ).

The biological activities of both $A$. ruber and A. flavus are represented in Table 1.

\section{Exploring the Cytotoxic Potential of Both Aspergillus Species Isolated Compounds Using Virtual Screening as Future Perspectives}

Cancer is the biggest health problem facing the healthcare system worldwide. The major challenge appears from its diverse etiology, and its hazardous consequence is that it ultimately lead to death. Although many therapeutic regimes and protocols were developed, most of these treatments are only effective with about $40 \%$ of the case based on early diagnosis. Another challenge merged significantly that involved a dramatic exponential increase in the new cancer cases in the last decade, especially in the developing countries. In the Eastern Mediterranean Region (EMR), the increase in the expected cases reaches 1.8 folds in the next few years. Thus, cancer is considered the second cause of death in the developing countries and the fourth cause in the EMR [35].

Nowadays, management of cancer can be achieved mainly through different guidelines that involve surgery, radiation, and the use of chemotherapeutic agents. Furthermore, modifications of the known anticancer drugs to overcome multidrug resistance mechanisms proved to be inefficient in the majority of cases, and this potentiates the 
<smiles>C=CC(C)(C)c1[nH]c2c(CC=C(C)C)cc(CC=C(C)C)cc2c1CC1N=C(O)[C@H](C)N=C1O</smiles>

Echinulin (1)<smiles>C=CC(C)(C)c1[nH]c2ccccc2c1CC1=NC(O)C(C)N=C1O</smiles><smiles>C=CC(C)(C)c1[nH]c2ccccc2c1/C=C\N=C(O)[C@H](C)N=CO</smiles>

Neoechinulin A (2)<smiles>Cc1cc(O)c2c(c1O)C(=O)c1c(O)cc(O)cc1C2=O</smiles>

Erythroglaucin (3)<smiles>COc1cc(O)c2c(c1)C(=O)c1cc(C)cc(O)c1C2=O</smiles>

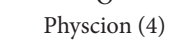<smiles>CC=CC=CCCc1c(O)cc(CC=C(C)C)c(O)c1C=O</smiles>

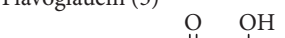

sodihydroauroglaucin (6)<smiles>CCCCC/C=C/c1c(O)cc(CC=C(C)C)c(C=O)c1O</smiles>

Tetrahydroauroglaucin (7) $\quad$ ON Epoxyisoechinulin A (8)<smiles>CC1NC(=O)C(Cc2cc3ccccc3[nH]2)NC1=O</smiles>

Cyclo(Trp-Ana) (10)<smiles>COc1cc(O)cc2c1C(=O)c1c(O)cc(CO)cc1C2=O</smiles><smiles></smiles>

Neochinulin E (12); R = O Neochinulin B (13); $\mathrm{R}=\mathrm{CH}_{2}$<smiles>C=CC(C)(C)C1=Nc2ccc(CC=C(C)C)cc2C1=Cc1[nH]c(=O)c(=O)[nH]c1O</smiles><smiles>C=CC(O)(O)c1[nH]c2ccc(CC=C(C)C)c(CC=C(C)C)c2c1/C=c1/nc(O)c(=C)nc1O</smiles><smiles>C=CC(C)(C)c1[nH]c2ccc(C[C@H](O)C(C)(C)O)cc2c1/C=C1/N=C(O)[C@H](C)N=C1O</smiles>

Dihydroxyisoechinulin A (17)

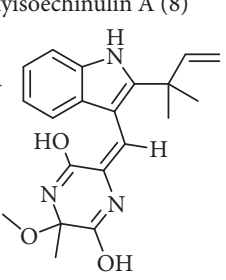

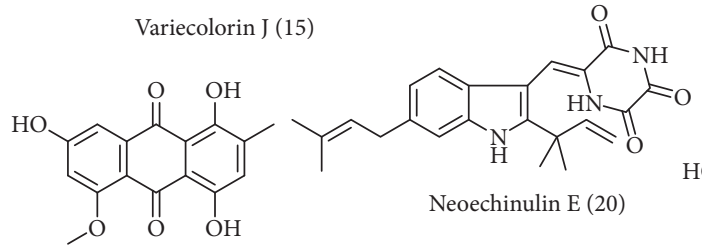

Neoechinulin E (20)<smiles>[R]c1cc(O)cc2c1OC(=O)c1c(O)cc(C)c(O)c1C2</smiles><smiles>COc1cc(O)cc2cc3c(c(O)c12)C(=O)CC(C)(O)C3</smiles>

1indole-3-carboxaldenhyde (18)

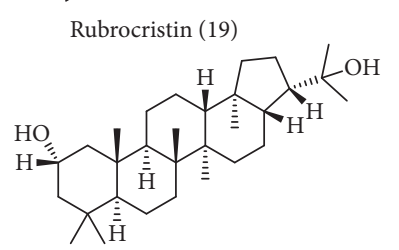

Eurotinone (21): $\mathrm{R}=\mathrm{OH}$ 2-Methyleurotinone (24); $\mathrm{R}=\mathrm{OCH}_{3}$ Asperflavin (22)<smiles>Cc1cc(O)c2c(c1OC(=O)O)C(=O)c1c(O)c(O)cc(O)c1C2=O</smiles>

1, 6, 8-Trihydroxy-4-benzoyloxy-3
methylanthraquinone (23)<smiles>COc1cc(O)cc2c1OC(=O)c1c(O)cc(C)cc1C2</smiles>
Catenarin (26) 2-O-Methyl-9-dehydroxyeurotinone (27)<smiles>C/C=C/C=C/CCc1c(O)cc(CC=C(C)C)c(O)c1C=O</smiles>
$\mathrm{OH}$ Isodihydroauroglaucin (28)

2-Hydroxydiplopterol (25)<smiles>COc1cc(=O)c2c(O)c3c(OC)cc(O)cc3c(-c3c(C)cc(OC)c4c(O)c5c(cc34)CC(O)(O)CC5=O)c2o1</smiles><smiles></smiles><smiles>C=CC(C)(C)c1[nH]c2ccc(CC=C(C)C)cc2c1/C=C1/N=C(O)[C@H]([18OH])N=C1O</smiles><smiles>C=CC(C)(C)c1[nH]c2ccc(C=CC(C)C)cc2c1/C=C\C=C(C)C</smiles>

Isoechinulin B (33)<smiles>C=CC(C)(C)c1[nH]c2ccc(CC3OC3(C)C)cc2c1/C=c1/nc(O)c(=C)nc1O</smiles>

Isoechinulin C (34)<smiles>C=CC(C)(C)c1[nH]c2ccccc2c1/C=C1\NC(=O)C(C)NC1=O</smiles>

Compound (35)<smiles>C=CC(C)(C)c1[nH]c2cc(CC=C(C)C)ccc2c1/C=C1\NC(=O)C(C)NC1=O</smiles>

Compound (36)

Figure 1: Secondary metabolites isolated from Aspergillus ruber.

need to search for new safer lead drugs with lower side effects. Natural resources still represent the main focus for discovery of novel anticancer leading entities, whereas $60 \%$ of drugs used in its management are supplied from nature. Recently, marine sponges were proclaimed to be an excellent source of novel, effective entities displaying potent 

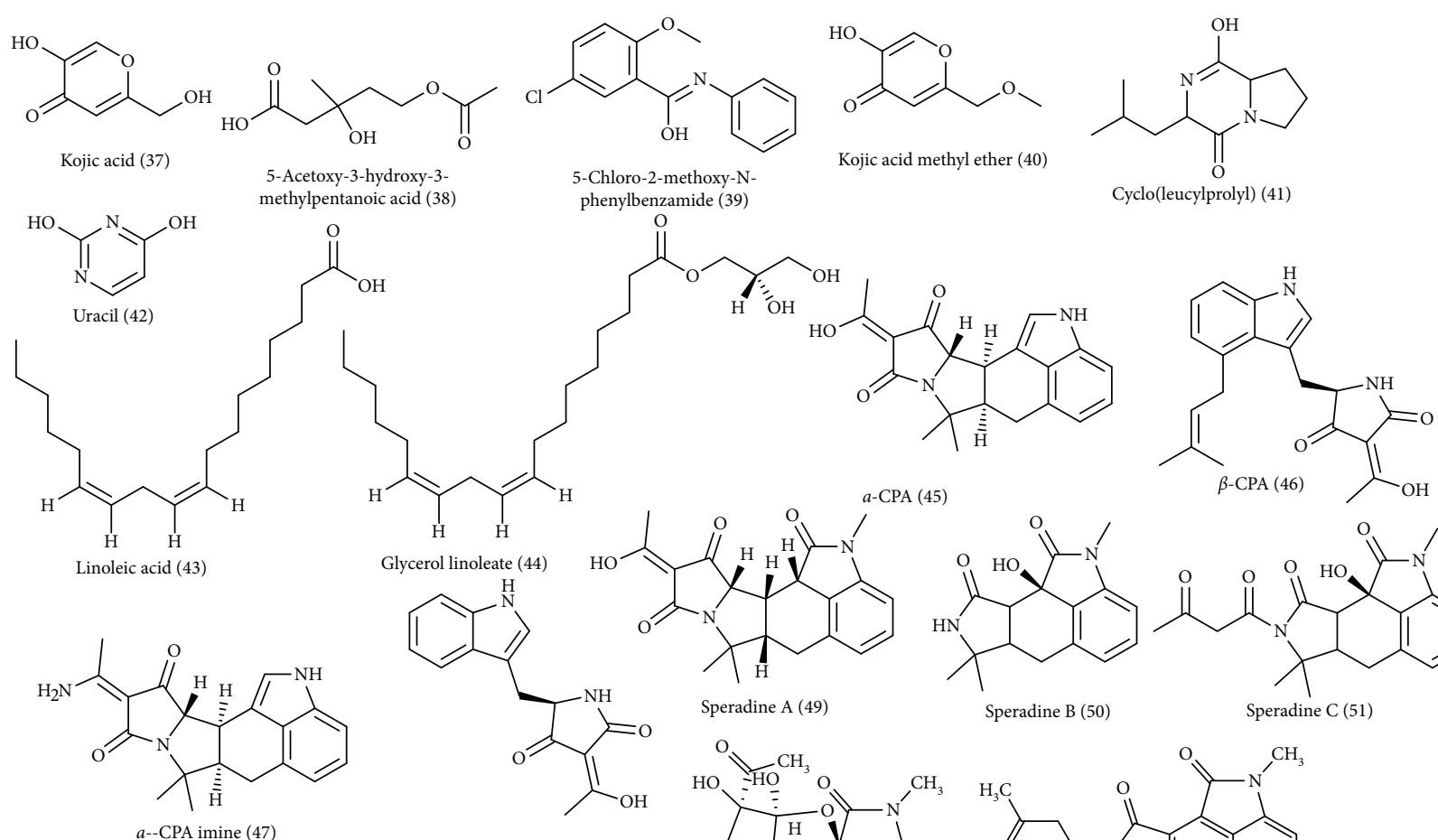

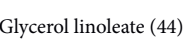<smiles>C/C=C(/O)CO</smiles><smiles>COC(=O)CC(=O)N1C(=O)C2C(Cc3cccc4c3[C@@]2(O)C(=O)N4C)C1(C)C</smiles>

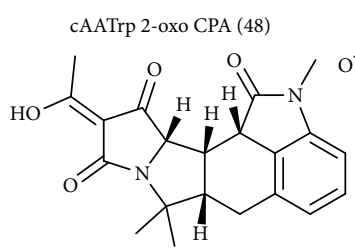<smiles>CN1C(=O)c2c3c(cc4cccc1c24)C(C)(C)NC3=O</smiles><smiles>CC(CCC(=O)O)N1C(=O)c2c3c(cc4cccc1c24)C(C)(C)N(C)C3=O</smiles>

Cyclopiamide A (56)

Cyclopiamide B (57)

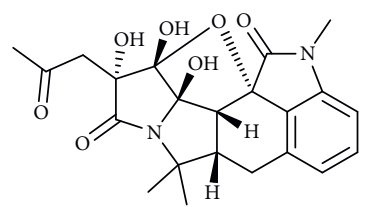<smiles>C/C=C\C(=O)C(N)CC(O)CS(=O)c1cc(O)c2cc1C(O)C(NC)C(O)=NC(C)C(O)=NC(C(O)=NCC(=O)O)C(C)(CC)O2</smiles><smiles>C[C@@H]1CCCC[C@@H](Cc2cc(O)cc(O)c2C(=O)O)O1</smiles>

Ustiloxin B (63)

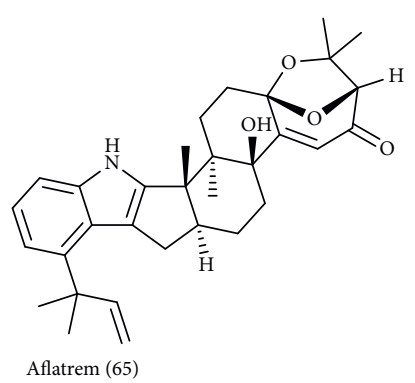

Asperentin (64)

Figure 2: Secondary metabolites isolated from Aspergillus flavus.

anticancer activity. Consequently, this encourages the investigation of related molecules. In spite of displaying a prominent activity in the experimental models, only few had passed to the clinical trials phase. Thus, there is an urgent demand for continual search for active compounds with neoteric nuclei [36].

Thus, molecular modelling studies were performed on crucial enzymes implicated in the formation, progression, and 
<smiles></smiles>

Asperorydine B (66)<smiles>CC1=CC(=O)OCC1</smiles>

4-Methyl-5, 6-dihydro-2H-pyran-2-one (67)<smiles>C/C=C/CC(=O)c1c(O)ccc(O)c1O</smiles>

Maltoryzine (68)<smiles>CC(O)CC(=O)N1C(=O)c2c(cc3cccc4c3c2C(=O)N4C)C1(C)C</smiles>

Asperorydine G (69)<smiles></smiles>

Asperorydine M (70)

Figure 3: Secondary metabolites isolated from Aspergillus flavus (continued).

Table 1: The biological activities of both A. ruber and A. flavus.

\begin{tabular}{|c|c|c|c|}
\hline Compound & Genus & Biological activity & References \\
\hline Flavoglaucin (5) & A. ruber & $\begin{array}{c}\text { Promising significant antiviral potential versus HSV-1 } \\
\text { virus displaying } \mathrm{EC}_{50} \text { value of } 6.95 \mu \mathrm{M} \\
\text { Moderate cytotoxic effect versus Vero cell }\end{array}$ & {$[10]$} \\
\hline Isodihydroauroglaucin (6) & A. ruber & $\begin{array}{c}\text { Promising significant antiviral potential versus HSV-1 } \\
\text { virus displaying } \mathrm{EC}_{50} \text { value of } 4.73 \mu \mathrm{M} \\
\text { Moderate cytotoxic effect versus Vero cell } \\
\text { Weak antibacterial effect }\end{array}$ & {$[10]$} \\
\hline Tetrahydroauroglaucin (7) & A. ruber & Notable antibacterial activity & {$[11,12]$} \\
\hline Isoechinulin A (32) & A. ruber & Potent inhibition to the growth of silkworm larvae & {$[14,15,21]$} \\
\hline Compounds (35-36) & A. ruber & Potent inhibition to the growth of silkworm larvae & {$[14,15,21]$} \\
\hline Kojic acid (37) & A. flavus & Promising whitening agent for the skin & [24]. \\
\hline Tannase enzyme & A. ruber & $\begin{array}{c}\text { Treatment of tannery effluents } \\
\text { Production of gallic acid }\end{array}$ & {$[22]$} \\
\hline Total extract & A. flavus & $\begin{array}{l}\text { Potent antifungal and antibacterial activity against many } \\
\text { common human pathogens. } \\
\text { Promising antioxidant activity manifested by its free } \\
\text { radical scavenging behavior towards DPPH. } \\
\text { Effective inhibition of RBC hemolysis by } 70 \% \text { (at } 2 \mathrm{mg} / \mathrm{mL} \text { of the } \\
\text { crude extract) comparable to } 78 \% \text { inhibition elicited by ibuprofen }\end{array}$ & {$[26]$} \\
\hline Amino peptidases & A. flavus & Functional potential of protein products and develop flavor to cheese & [27] \\
\hline
\end{tabular}

metastasis of cancer which are human cyclin-dependent kinase 2 (CDK-2) (PDB ID 1PXP, $2.30 \AA$ ), human DNA topoisomerase II (TOP-2) (PDB ID 4G0U, $2.70 \AA$ ), and matrix metalloprotinase 13 (MMP-13) (PDB ID 1XUD, $1.8 \AA$ ). In silico studies were performed on the previously listed enzymes which were downloaded from protein data bank (http://www.pdb. org) using Discovery Studio 2.5 (Accelrys Inc., San Diego, CA, USA), adopting C-docker protocol. Free binding energies $(\Delta G)$ were calculated as mentioned previously for the most stable docking poses [37-39].
The three enzymes chosen to test the probable cytotoxic potential of the identified enzymes are human cyclin-dependent kinase, human DNA topoisomerase II, and matrix metalloproteinases (MMPs). Human cyclin-dependent kinases constitute enzyme collection that tremendously affects cell cycle occurrence and transcription. CDK2 firmly binds to cyclin A and $E$ forming a complex with the latter that involved in the G1- to S-phase transition while its complex with the former eventually causes cell cycle progression via the $S$ to $M$ phase. Therefore, CDK2 inhibition resulted in an effective cell 
TABLE 2: Free binding energies $(\Delta \mathrm{G})$ in $\mathrm{kcal} / \mathrm{mol}$ for compounds identified from $A$. ruber and $A$. flavus in human cyclin-dependent kinase 2 (CDK-2), DNA topoisomerase II (TOP-2), and matrix metalloprotinase 13 (MMP-13) active centers using C-docker protocol.

\begin{tabular}{|c|c|c|c|}
\hline Compound & CDK-2 & TOP-2 & MMP-13 \\
\hline Echinulin (1) & 14.07 & 26.35 & FD \\
\hline Neoechinulin A (2) & -22.96 & -5.07 & -26.00 \\
\hline Erythroglaucin (3) & -37.21 & -19.45 & -35.68 \\
\hline Physcion (4) & -35.63 & -16.23 & -32.68 \\
\hline Flavoglaucin (5) & -21.40 & -3.53 & -25.23 \\
\hline Isodihydroauroglaucin (6) & -0.82 & 15.03 & -2.97 \\
\hline Tetrahydroauroglaucin (7) & -8.02 & 8.27 & -15.45 \\
\hline Epoxyisoechinulin A (8) & -22.39 & -2.13 & -8.94 \\
\hline Preechinulin (9) & -21.94 & -10.72 & -20.062 \\
\hline Cyclo(Trp-Ana) (10) & -26.50 & -14.94 & -29.04 \\
\hline Questinol (11) & -37.08 & -19.77 & -33.94 \\
\hline Neochinulin $E(12)$ & -17.39 & -7.88 & -18.84 \\
\hline Neochinulin B (13) & -21.03 & -4.82 & -22.88 \\
\hline Variecolorin H (14) & -16.99 & -36.51 & -24.82 \\
\hline Variecolorin $J(15)$ & FD & 36.51 & 29.86 \\
\hline Cryptoechinuline $G(16)$ & 15.29 & 30.36 & FD \\
\hline Dihydroxyisoechinulin A (17) & -25.96 & -5.31 & -8.262 \\
\hline 2-(1_1-Dimethyl-2-propen1-yl)-1H-indole-3-carboxaldenhyde (18) & -15.05 & -5.94 & -19.58 \\
\hline Rubrocristin (19) & -36.00 & -17.65 & -30.94 \\
\hline Neoechinulin $E(20)$ & -5.90 & 11.03 & -7.58 \\
\hline Eurotinone (21) & -23.47 & -11.828 & -25.39 \\
\hline Asperflavin (22) & -17.88 & -5.264 & -14.27 \\
\hline 1,6,8-Trihydroxy-4-benzoyloxy-3-methylanthraquinone (23) & -47.41 & -23.38 & -37.81 \\
\hline 2-Methyleurotinone (24) & -20.48 & -7.72 & -19.16 \\
\hline 2-Hydroxydiplopterol (25) & 94.27 & 80.51 & FD \\
\hline Catenarin $(26)$ & -5.05 & -5.07 & -4.66 \\
\hline 2-O-Methyl-9-dehydroxyeurotinone (27) & -18.19 & -7.014 & -21.30 \\
\hline Isodihydroauroglaucin $(28)$ & -0.82 & 15.02 & -2.97 \\
\hline Asperinine A (29) & FD & 22.17 & FD \\
\hline Asperinine B (30) & FD & 26.36 & FD \\
\hline Erythroglaucin (31) & -37.21 & -19.45 & -35.68 \\
\hline Isoechinulin A (32) & -1.36 & 14.23 & 11.73 \\
\hline Isoechinulin B (33) & -8.89 & 14.26 & 1.85 \\
\hline Isoechinulin C (34) & -26.94 & -3.48 & -6.28 \\
\hline Compound (35) & -20.47 & -3.81 & -21.91 \\
\hline Compound (36) & -5.61 & 15.21 & -1.61 \\
\hline Kojic acid $(37)$ & -16.53 & -10.71 & -16.37 \\
\hline 5-Acetoxy-3-hydroxy-3-methylpentanoic acid (38) & -25.67 & -19.78 & -29.52 \\
\hline 5-Chloro-2-methoxy-N-phenylbenzamide (39) & -28.82 & -11.4486 & -32.0189 \\
\hline Kojic acid methyl ether (40) & -16.99 & -10.3046 & -18.7795 \\
\hline Cyclo(leucylprolyl) (41) & -13.27 & -2.68683 & -18.1432 \\
\hline Uracil (42) & -23.44 & 33.38 & -24.07 \\
\hline Linoleic acid (43) & -20.39 & -0.25 & -23.88 \\
\hline Glycerol linoleate (44) & -21.40 & 1.915 & -25.87 \\
\hline$\alpha$-CPA (45) & 18.63 & 30.26 & 45.24 \\
\hline$\beta-\mathrm{CPA}(46)$ & 6.77 & 25.60 & 4.12 \\
\hline$\alpha$-CPA imine $(47)$ & 22.87 & 33.67 & 39.92 \\
\hline cAATrp 2-oxo CPA (48) & -10.64 & 2.20 & -15.32 \\
\hline Speradine B (50) & 6.99 & 16.18 & 9.94 \\
\hline Speradine C (51) & -5.16 & 13.21 & 15.64 \\
\hline Speradine $D(52)$ & -4.62 & 13.76 & 16.68 \\
\hline 3-OH-speradine A (53) & 47.50 & 49.92 & FD \\
\hline Speradine F (54) & 70.29 & 48.89 & FD \\
\hline Speradine H (55) & 17.00 & 35.30 & 26.63 \\
\hline Cyclopiamide A (56) & 29.32 & 38.30 & 27.17 \\
\hline Cyclopiamide B (57) & 14.91 & 34.73 & 20.46 \\
\hline Cyclopiamide C (58) & 17.89 & 32.15 & 23.19 \\
\hline Cyclopiamide $D(59)$ & 20.78 & 31.61 & 21.79 \\
\hline Cyclopiamide $E(60)$ & 29.65 & 50.31 & 47.67 \\
\hline
\end{tabular}


TABLE 2: Continued.

\begin{tabular}{lccc}
\hline Compound & CDK-2 & TOP-2 & MMP-13 \\
\hline Cyclopiamide F (61) & 30.32 & 40.30 & 29.17 \\
Cyclopiamide J (62) & 36.08 & 50.93 & FD \\
Ustiloxin B (63) & -21.82 & 4.91 & FD \\
Asperentin (64) & -25.95 & -7.46 & -25.53 \\
Aflatrem (65) & 75.33 & 84.32 & FD \\
CK8 (CDK-2 inhibitor) & -39.34 & ND \\
Doxorubicin (TOP-2 inhibitor) & -39.99 & -15.98 & ND \\
PB4 (MMP-13 inhibitor) & ND & ND & -16.29 \\
\hline
\end{tabular}

Positive values indicate unfavorable interaction. FD, fail to dock; ND, not done; CK8, N-[4-(2,4-dimethyl-thiazol-5-yl)-pyrimidin-2-yl]- $\mathrm{N}^{\prime}$, $\mathrm{N}^{\prime}$-dimethylbenzene-1,4-diamine; PB4, N, N'-bis (4-fluoro-3-methylbenzyl) pyrimidine-4,6-dicarboxamid.
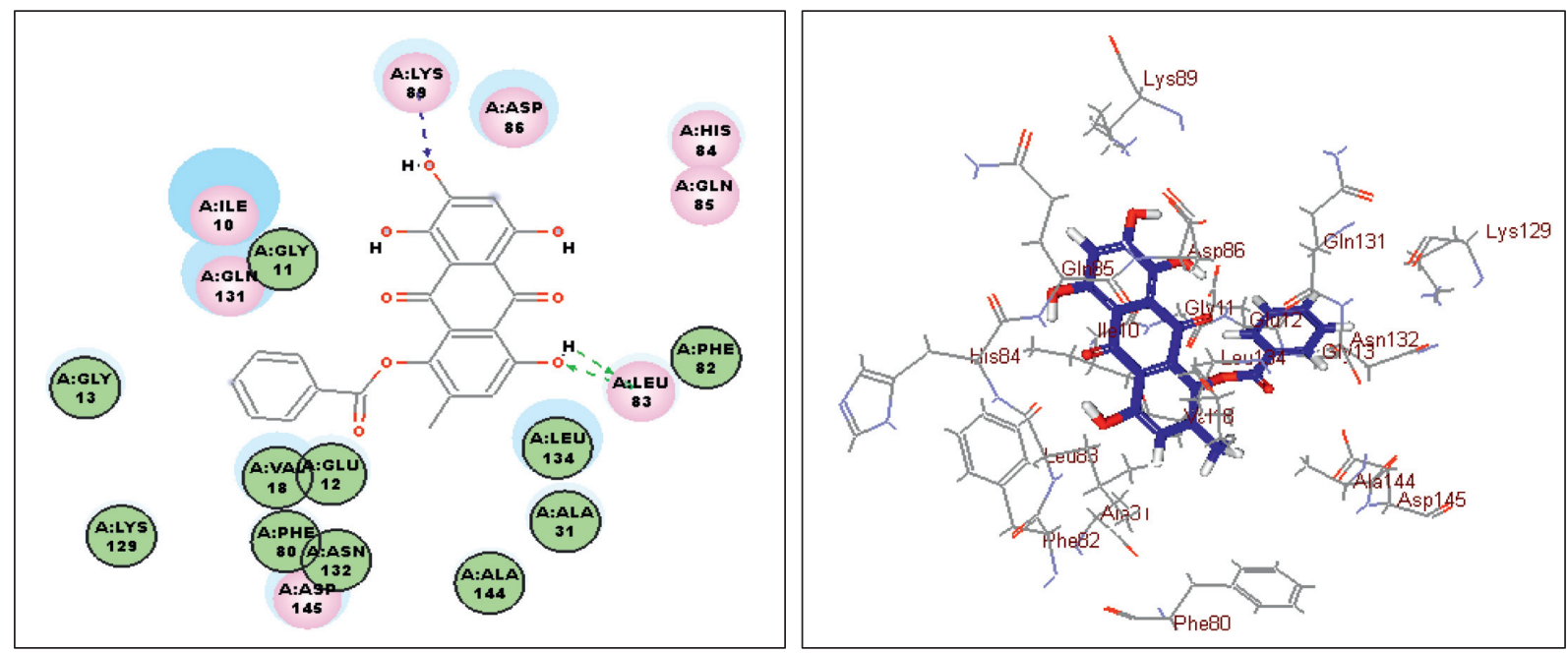

(a)
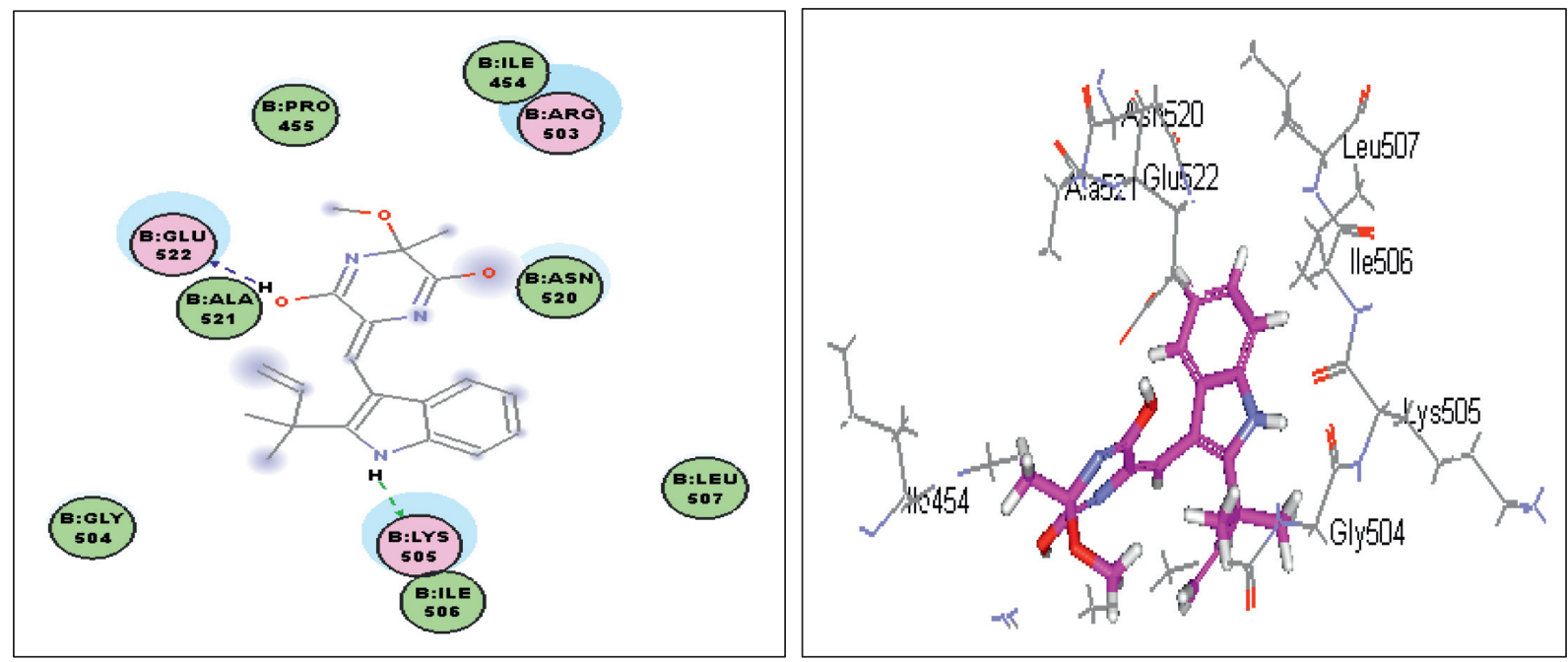

(b)

FIgURE 4: Continued. 

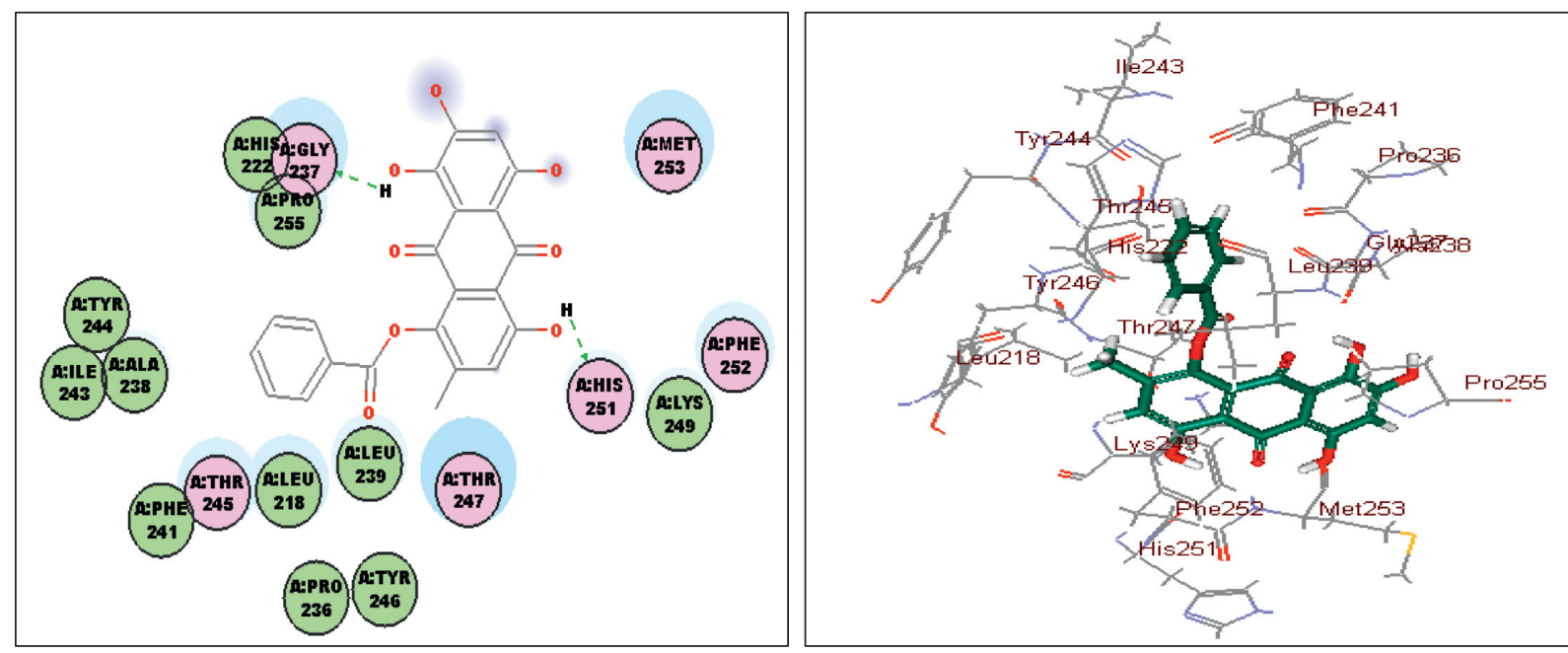

(c)

FIGURE 4: 2D and 3D binding mode of 1,6,8-trihydroxy-4-benzoyloxy-3-methylanthraquinone (23) in the active center of human cyclin-dependent kinase 2 (CDK-2) (a), variecolorin $\mathrm{H}$ (14) in the active center of DNA topoisomerase II (TOP-2) (b), and 1,6,8-trihydroxy-4-benzoyloxy-3 methylanthraquinone (23) in the active center of matrix metalloprotinase 13 (MMP-13) (c) active centers using C-docker protocol.

proliferation inhibition and consequently arrested cancer progression [40]. However, human DNA topoisomerase II adjusts the critical functions within the cells by causing massive changes with respect to the shape of alteration regarding the chromosomal DNA structure resulting in DNA unwinding affecting cell survival [41]. Regarding matrix metalloproteinases (MMPs), they are group of enzymes that are able to decompose extracellular matrix of vital components that promptly leads to cancer cell growth and metastasis and thus their inhibition constitutes an advanced strategy in combating cancer [42].

Data obtained from virtual screening of the identified compounds in the active pockets of human cyclin-dependent kinase 2 (CDK-2), human DNA topoisomerase II (TOP-2), and matrix metalloprotinase 13 (MMP-13) revealed that some of the docked compounds showed considerable binding affinities towards the tested proteins; however, others showed weak interactions manifested by the positive values of $\Delta \mathrm{G}$. Meanwhile 1,6,8-trihydroxy-4-benzoyloxy-3-methylanthraquinone (23) revealed the most firm fitting with the active pockets of both CDK-2 and MMP-13 displaying free binding energies of -47.41 and $-37.81 \mathrm{kcal} / \mathrm{mole}$, respectively. It showed superior binding when compared to Doxorubicin, the potent standard anticancer agent and to CK8 (CDK-2 inhibitor) but moderate activity when compared to PB4 (MMP-13 inhibitor). However, variecolorin $\mathrm{H}$ (14) showed the highest fitting score within the active center of TOP-2 with $\Delta \mathrm{G}$ equal to $-36.51 \mathrm{kcal} / \mathrm{mole}$ exceeding that of doxorubicin that showed $-15.98 \mathrm{kcal} / \mathrm{mole}$ as free binding energy (Table 2).

The highest fitting of 1,6,8-trihydroxy-4-benzoyloxy-3methylanthraquinone (23) could be explained by the virtue of formation of multiple bonds with the amino acid residues present at the active site represented by the formation of three $\mathrm{H}$ - bonds with Leu 83 and Lys 89 at CDK-2 active center and two H- bonds with Gly 237 and His 251 at MMP13 active pocket. Meanwhile, variecolorin $\mathrm{H}$ (14) formed two
H- bonds with Glu 522 and Lys 505 at TOP-2 active site as revealed in Figure 4.

\section{Conclusion}

In this study, it was concluded that nearly about seventy secondary metabolites were isolated from two Aspergillus species, namely, Aspergillus ruber and Aspergillus flavus. They were unambiguously elucidated employing one- and two-dimensional nuclear magnetic resonance (1D and 2D NMR) in addition to high resolution mass spectrometry (HRMS). Some of them displayed promising anticancer, antiviral, and antimicrobial activities; meanwhile, the others displayed no activity that necessitates further investigation. In silico studies judged by different proteins, inhibition revealed that some of the identified compounds showed considerable cytotoxic potential with 1,6,8-trihydroxy-4benzoyloxy-3-methylanthraquinone and variecolorin $\mathrm{H}$ exhibited the highest activity. Further in vitro followed by in vivo studies should be conducted to confirm the in silico studies. Thus, more highlights should be shed on the discovery of new drug entities combating cancer and other debilitating disorders derived from fungal metabolites.

\section{Conflicts of Interest}

The authors declare no conflicts of interest.

\section{Acknowledgments}

The authors acknowledge STDF (Egyptian Science and Technology Development Funds) for its financial support under grant number NCP 25927 entitled "Drug discovery of new anti-infective and anticancer agents from marine organisms and their associated micro-organisms". 


\section{References}

[1] L. Jin, C. Quan, X. Hou, and S. Fan, "Potential pharmacological resources: natural bioactive compounds from marinederived fungi," Marine Drugs, vol. 14, no. 4, p. 76, 2016.

[2] M. E. Rateb and R. Ebel, "Secondary metabolites of fungi from marine habitats," Natural Product Reports, vol. 28, no. 2, pp. 290-344, 2011.

[3] J. W. Blunt, B. R. Copp, R. A. Keyzers, M. H. G. Munro, and M. R. Prinsep, "Marine natural products," Natural Product Reports, vol. 32, no. 2, pp. 116-211, 2015.

[4] H. K. Kang, H. H. Lee, C. H. Seo, and Y. Park, "Antimicrobial and immunomodulatory properties and applications of marine-derived proteins and peptides," Marine Drugs, vol. 17, no. 6, p. 350, 2019.

[5] J. W. Blunt, B. R. Copp, R. A. Keyzers, M. H. G. Munro, and M. R. Prinsep, "Marine natural products," Natural Product Reports, vol. 34, no. 3, pp. 235-294, 2017.

[6] F. S. Youssef, M. L. Ashour, A. N. B. Singab, and M. Wink, “A Comprehensive review of bioactive peptides from marine fungi and their biological significance," Marine Drugs, vol. 17, no. 10, p. $559,2019$.

[7] N. M. Abdel-Wahab, H. Harwoko, W. E. G. Müller et al., "Cyclic heptapeptides from the soil-derived fungus Clonostachys rosea," Bioorganic \& Medicinal Chemistry, vol. 27, no. 17, pp. 3954-3959, 2019.

[8] X. Liang, X.-H. Nong, Z.-H. Huang, and S.-H. Qi, “Antifungal and antiviral cyclic peptides from the deep-sea-derived fungus Simplicillium obclavatum Eiodsf 020," Journal of Agricultural and Food Chemistry, vol. 65, no. 25, pp. 5114-5121, 2017.

[9] D. H. El-Kashef, F. S. Youssef, R. Hartmann et al., "Azaphilones from the red sea fungus Aspergillus falconensis," Marine Drugs, vol. 18, no. 4, p. 204, 2020.

[10] D. H. El-Kashef, F. S. Youssef, I. Reimche et al., "Polyketides from the marine-derived fungus aspergillus falconensis: in silico and in vitro cytotoxicity studies," Bioorganic \& $\mathrm{Me}$ dicinal Chemistry, vol. 29, p. 115883, 2020.

[11] T.-M. Liang, Y.-W. Fang, J.-Y. Zheng, and C.-L. Shao, "Secondary metabolites isolated from the Gorgonian-derived fungus Aspergillus ruber and their antiviral activity," Chemistry of Natural Compounds, vol. 54, no. 3, pp. 559-561, 2018.

[12] O. F. Smetanina, A. I. Kalinovskii, Y. V. Khudyakova, N. N. Slinkina, M. V. Pivkin, and T. A. Kuznetsova, "Metabolites from the marine fungus Eurotium repens," Chemistry of Natural Compounds, vol. 43, no. 4, pp. 395-398, 2007.

[13] T. Hamasaki, M. Fukunaga, Y. Kimura, and Y. Hatsuda, "Isolation and structures of two new metabolites fromAspergillus ruber," Agricultural and Biological Chemistry, vol. 44, no. 7, pp. 1685-1687, 1980.

[14] Y.-F. Li, X.-B. Wu, S.-I. Niaz et al., "Effect of culture conditions on metabolites produced by the crinoid-derived fungus Aspergillus ruber 1017," Natural Product Research, vol. 31, no. 11, pp. 1299-1304, 2017.

[15] G. Gatti, R. Cardillo, and C. Fugant, "Molecular structure of cryptoechinuline $\mathrm{g}$, an isoprenylated dehydrotryptophan metabolite isolated from aspergillus ruber," Tetrahedron Letters, vol. 19, no. 29, pp. 2605-2606, 1978.

[16] H. Raistrick, R. Robinson, and D. E. White, "Studies in the biochemistry of micro-organisms," Biochemical Journal, vol. 30 , no. 8 , p. $1303,1936$.

[17] K. Arai, Y. Aoki, and Y. Yamamoto, "Asperinines A and B, dimeric tetrahydroanthracene derivatives from Aspergillus ruber," Chemical \& Pharmaceutical Bulletin, vol. 37, no. 3, pp. 621-625, 1989.

[18] G. W. Engstrom, R. E. Stenkamp, D. J. McDorman, and L. H. Jensen, "Spectral identification, X-Ray structure determination and iron-chelating capability of Erythroglaucin, a red pigment from Aspergillus ruber," Journal of Agricultural and Food Chemistry, vol. 30, no. 2, pp. 304-307, 1982.

[19] G. W. Engstrom, D. J. McDorman, and M. J. Maroney, "Iron chelating capability of physcion, a yellow pigment from Aspergillus ruber," Journal of Agricultural and Food Chemistry, vol. 28, no. 6, pp. 1139-1141, 1980.

[20] H. Nagasawa, A. Isogai, A. Suzuki, and S. Tamura, "13C-NMR Spectra and streochemistry of isoechinulins a, B and C," Agricultural and Biological Chemistry, vol. 43, no. 8, pp. 1759-1763, 1979.

[21] H. Nagasawa, A. Isogai, A. Suzuki, and S. Tamura, "Structures of isoechinulins A, B and C, new indole metabolites from aspergillus ruber," Tetrahedron Letters, vol. 17, no. 19, pp. 1601-1604, 1976.

[22] H. Nagasawa, A. Isogai, K. Ikeda et al., "Isolation and structure elucidation of a new indole metabolite fromAspergillus ruber," Agricultural and Biological Chemistry, vol. 39, no. 9, pp. 1901-1902, 1975.

[23] R. Kumar, J. Sharma, and R. Singh, "Production of tannase from Aspergillus ruber under solid-state fermentation using Jamun (Syzygium cumini) leaves," Microbiological Research, vol. 162, no. 4, pp. 384-390, 2007.

[24] T. E. Cleveland, J. Yu, N. Fedorova et al., "Potential of Aspergillus flavus genomics for applications in biotechnology," Trends in Biotechnology, vol. 27, no. 3, pp. 151-157, 2009.

[25] L. Sudarshan, K. Vikram, C. Jignesh et al., "Biochemical isolation and characterization of kojic acid derived from Aspergillus oryzae and Aspergillus flavus," Resarch Journal of Biotechnology, vol. 13, pp. 30-35, 2018.

[26] E. M. Eliwa, M. M. El-Metwally, A. H. Halawa et al., "New bioactive metabolites from Aspergillus flavus 9afl," Journal of Atoms and Molecules, vol. 7, p. 1045, 2017.

[27] M. P. Patil, R. H. Patil, and V. L. Maheshwari, "Biological activities and identification of bioactive metabolite from endophytic Aspergillus flavus L7 Isolated from Aegle marmelos," Current Microbiology, vol. 71, no. 1, pp. 39-48, 2015.

[28] N. Sriram, M. Priyadharshini, and S. Sivasakthi, "Production and characterization of amino peptidase from marine Aspergillus flavus," International Journal of Microbiology Research, vol. 3, pp. 221-226, 2012.

[29] V. Uka, G. Moore, N. Arroyo-Manzanares, D. Nebija, S. De Saeger, and J. Diana Di Mavungu, "Unravelling the diversity of the cyclopiazonic acid family of mycotoxins in Aspergillus flavus by UHPLC triple-TOF HRMS," Toxins, vol. 9, no. 1, p. 35, 2017.

[30] J. F. Grove, "New metabolic products of Aspergillus flavus. Part I. Asperentin, its methyl ethers, and 5'-hydroxyasperentin," Journal of the Chemical Society, Perkin Transactions 1, vol. 1, pp. 2400-2406, 1972.

[31] M. Umemura, N. Nagano, H. Koike et al., "Characterization of the biosynthetic gene cluster for the ribosomally synthesized cyclic peptide ustiloxin B in Aspergillus flavus," Fungal Genetics and Biology, vol. 68, pp. 23-30, 2014.

[32] S. Zhang, B. J. Monahan, J. S. Tkacz, and B. Scott, "Indolediterpene gene cluster from Aspergillus flavus," Applied and Environmental Microbiology, vol. 70, no. 11, pp. 6875-6883, 2004. 
[33] D. K. Mahato, K. E. Lee, M. Kamle et al., "Aflatoxins in food and feed: an overview on prevalence, detection and control strategies," Frontiers in Microbiology, vol. 10, 2019.

[34] Y. Elkhawas, N. Mostafa, A. Elissawy et al., "Lc/Ms of the soft coral Sarcophyton ehrenbergi and its isolated associated endophytic fungi: Aspergillus oryzae and Aspergillus flavus," Planta Medica, vol. 85, 2019.

[35] A. Acs, Cancer Facts and Ffgures 2010, pp. 1-44, American Cancer Society, National Home Office, Atlanta, GA, USA, 2010.

[36] J. E. John, "Natural products as lead-structures: a role for biotechnology," Drug Discovery Today, vol. 15, no. 11-12, pp. 409-410, 2010.

[37] A. A. Thabet, F. S. Youssef, M. El-Shazly, H. A. El-Beshbishy, and A. N. B. Singab, "Validation of the antihyperglycaemic and hepatoprotective activity of the flavonoid rich fraction of Brachychiton rupestris using in vivo experimental models and molecular modelling," Food and Chemical Toxicology, vol. 114, pp. 302-310, 2018.

[38] M. L. Ashour, F. S. Youssef, H. A. Gad et al., "Evidence for the anti-inflammatory activity of Bupleurum marginatum (Apiaceae) extracts using in vitro and in vivo experiments supported by virtual screening," Journal of Pharmacy and Pharmacology, vol. 70, no. 7, pp. 952-963, 2018.

[39] A. A. Janibekov, F. S. Youssef, M. L. Ashour, and N. Z. Mamadalieva, "New flavonoid glycosides from two Astragalus species (Fabaceae) and validation of their antihyperglycaemic activity using molecular modelling and in vitro studies," Industrial Crops and Products, vol. 118, pp. 142-148, 2018.

[40] O. F. Smetanina, A. I. Kalinovsky, Y. V. Khudyakova et al., "Indole alkaloids produced by a marine fungus isolate ofPenicillium janthinellumBiourge," Journal of Natural Products, vol. 70, no. 6, pp. 906-909, 2007.

[41] S. Niu, N. Wang, C.-L. Xie et al., "Roquefortine J, a novel roquefortine alkaloid, from the deep-Sea-derived fungus Penicillium granulatum Mccc 3a00475," The Journal of Antibiotics, vol. 71, no. 7, pp. 658-661, 2018.

[42] Y.-Q. Fan, P.-H. Li, Y.-X. Chao et al., "Alkaloids with cardiovascular effects from the marine-derived fungus Penicillium expansum Y32," Marine Drugs, vol. 13, no. 10, pp. 6489-6504, 2015. 